\title{
[POCO DESPUÉS DE EMPEZAR A PEDALEAR...]
}

\section{Eduardo MOGA}

\section{A Antonio Gamoneda}

$\mathrm{P}$ oco después de empezar a pedalear, noto un pinchazo en los muslos; en realidad, no es un pinchazo, sino un repentino embotamiento, como si los músculos se amaderaran, o como si tuviese melaza en lugar de piernas. Esta torpeza es, de hecho, el resultado de una nueva fluidez: el oxígeno adicional que aporta el corazón expande las paredes arteriales y las fibras del sartorio, y produce el dolor. Aparto mi atención de las piernas [con lo que mis piernas desaparecen; en un reportaje televisivo, un tatuador insertaba un piercing en el glande de un tatuado y, cuando le preguntaban por el dolor que éste pudiera sentir, respondía: «El dolor no existe»] y empiezo a sudar. El cuerpo se enciende, y su encendimiento es líquido. Me envuelve la piel; soy la piel: su extensión inconsútil, su lividez de túnica. Experimento su dilatación inmóvil, que quema. Y el sudor, esmalte u ocultación, distribuye sus escamas.

[Mientras pedaleo, veo un programa para sordos, pero, como nunca traigo auriculares, no lo oigo.

Fuera, el sol tropieza con las sombras. La arcilla lo amortigua, primero, y lo absorbe, después. (Through the leaves/ The sun a soundless pattern weaves/ Upon the floor, ha escrito Faulkner). Pero el calor que desprende produce espejismos: el aire se hace visible (el aire es la forma y lo que rodea a la forma, lo sólido y lo que niega lo sólido). La hierba se acolcha de luz. Un sirimiri solar penetra en los urinarios, cuyos espejos, moteados de oro, se resquebrajan en astillas gualdas (he leído en el fluvial Incurable, de David Huerta, muchas imágenes memorables, como «espejos nómadas». Me gustaría emplearla, y quizás éste fuera el lugar adecuado: en su explosión de reflejos, los espejos se esparcen por doquier: se hacen itinerantes. Sin embargo, no consigo incorporarla al poema sin sentir una íntima torcedura: la que produce el choque de una sinusoide y una tangente [o de una fuga y un staccato]. Incurable es un libro bestial: lucreciano, amazónico. Acudo a él para surtirme de metáforas o, más bien, de la ebriedad necesaria para crearlas. Pero, al leerlo, prevalece el sentimiento de que los versos se enredan como las extremidades filamentosas de las medusas, de que su proliferación no está eslabonada, sino blandamente yuxtapuesta: la percepción, por ende, no arraiga, como no lo hacen los 
árboles en los arenales ni en los glaciares, sino que resbala por una superficie galvanizada, impermeable en su multiplicidad)].

Remo. No repito los movimientos: los movimientos me repiten a mí. El sudor me acoraza. El corazón pertenece a un decapitado: late sin existencia. Los pulmones crujen como un pergamino rozado por un pájaro. Nada se dispersa: las moléculas se desbocan, pero hacia su fuego, hacia su significado, germen hostil de una nueva comparecencia; se desata el ácido láctico, que cristaliza en hexágonos sombríos, ubicuos como líquenes aferrados a sus escollos. La tenacidad cinética -el movimiento antes circular, ahora lineal- reproduce la tenacidad de la sangre, y la respiración de los párpados, y la abrasión de la conciencia. Me dilato como una bandada acosada por una rapaz; luego, me dirimo, me contraigo, estornudo: soy. Y repito la flexión como si rubricase, una y otra vez, un documento de aire. En el espejo, otro rema. Lleva mi ropa y su espalda se dobla como la mía, pero es otro. Preso en el azogue, no va a ningún sitio. Yo, en cambio, avanzo en la quietud. Recorro el punto en el que me encuentro, como si labrara una tierra sin suelo. Y el cuerpo viene a mí, desde muy lejos, estallando en piel, enterrándome en piel, con junturas de impaciencia, como si no viviera. El cuerpo subsana mis intermitencias -o las unifica en una intermitencia sin fin-, inclemente en su combustión, ávido de vértices, ajeno a la sequedad y las lágrimas. El cuerpo me aquieta, aunque me agite. Yo soy los intestinos que obran como huesos, los huesos que confundo con pájaros, el cuello visitado por relámpagos, el ano que se compadece en el sillín.

[Salgo a por un vaso de leche. No deja de sorprenderme que los óleos que nos regalara MarieAlice hace casi dos años, colgados junto a la puerta de mi despacho, no se hayan secado todavía. Los grumos de pintura siguen blandos: si se tocan, se deforman. Ella murió en abril. Que la pintura continúe fresca se me antoja una metáfora de su presencia, como si su mano sostuviera aún el pincel y pudiera modificar el curso de las líneas o el grosor de los trazos].

[Saludo a María, que pasea su aburrimiento por el gimnasio casi vacío. Cuando ha pasado, observo su cuerpo de esquisto, suma de semiesferas. Buceo en sus nalgas, que se ofrecen como geodas. En su arranque, reciben la curvatura del sacro; luego, acrecidas por los glúteos, describen una elipse cerámica, de duna glaseada por el ocaso, y desembocan en lo doble, que es también lo interior].

[Oigo un tren que pasa, un coche que pasa, un perro que ladra (agudamente), un niño que llora].

Caigo en el cuerpo, como en un abismo salpicado de hastío. El cuerpo es incomprensible: puede soportar la esquizofrenia o el cáncer, pero no tolera un alfilerazo. Fonollosa ha escrito: «Al nacer me asignaron, como a todos,/ un frágil esqueleto muy pequeño./ Le acepté y me cuidé que, año tras año,/ creciéramos los dos al mismo tiempo.// Y convivimos juntos». [Se titula «Zeleste 4» y pertenece a Ciudad del hombre: Barcelona. Me gusta este poema, aunque esté plagado de errores: la necesidad de preservar el endecasílabo obliga a su autor a infringir el régimen preposicional de los verbos - debería ser «me cuidé de que...»-; luego escribe: «le animo/ que haga el amor con otros esqueletos», y habría de ser: «le animo a que haga el amor...»; por no hablar del horrendo leísmo «le acepté...» o de la 
redundancia del último verso: toda convivencia implica juntura. Tiendo a creer que un escritor que no sepa manejar correctamente el instrumento con el que trabaja no puede ser un buen escritor, pero la realidad me contradice: es obvio, y hasta frecuente, que autores dotados de mucha imaginación, gran fuerza expresiva y una aptitud natural para conectar con la sensibilidad del lector, cometen repeticiones groseras, faltas de ortografía y, aún peor, estruendosos anacolutos. Otros, en cambio, pulcros y perfectos (¿me contaré yo entre ellos?), son incapaces de escribir nada plausible]. En el cuerpo encuentro el lápiz con el que escribo, las manos con las que tiro de las asas que hacen las veces de remos, la ensoñación de María desnuda, la gota de sudor que me cruza la frente y se queda colgando en la punta de la nariz, desde donde cae al parqué [de iroko], la respiración inflamada, el reloj que señala la una menos veinte, los chillidos azules de los que se chapuzan en la piscina, incendiada de abejas y de laxitud. Sin embargo, me gustaría que no hubiera cuerpo. Que sus cuadernas rechinaran en silencio, y que su corazón no fuera un músculo, sino una sombra, y que los engranajes que me permiten escribir -las sinapsis y los cóndilos, los huesecillos y las membranas- fuesen coágulos de nada: que su materia fuera la inexistencia; y, aun así, ser. Me gustaría que me arrastrara la rotación de estos pedales, o las rotaciones invisibles de las que formo parte [ ¿a qué velocidad se desplaza un cuerpo, teniendo en cuenta la velocidad a la que la tierra gira sobre sí misma y orbita alrededor del sol, y la velocidad a la que se expande el universo?], o la del neutrón uncido a su núcleo, o la de la sangre en las venas, que choca contra los islotes de colesterol como las aguas de un río contra las piedras de su cauce: que me indujeran a su caos de cosas sin amor; que me depositaran en su vergel exangüe. Diluirme y ser. Y entrar en ese vacío de mí. Pero vivir: en un cuerpo ilimitado, en una oquedad plena.

La bicicleta elíptica siempre me ha costado mucho.

María vuelve a sonreírme.

El sol quema con cautela. 